\title{
Evaluation and identification of stem rust resistance genes Sr2, Sr24, Sr25, Sr26, Sr31 and Sr38 in wheat lines from Gansu Province in China
}

\author{
Xiao Feng Xu ${ }^{1}$, Dan Dan Li ${ }^{1}$, Yang Liu ${ }^{1}$, Yue Gao ${ }^{1}$, Zi Yuan Wang ${ }^{1}$, Yu Chen Ma ${ }^{1}$, Shuo Yang ${ }^{1}$, Yuan Yin \\ Cao ${ }^{1}$, Yuan Hu Xuan ${ }^{\text {Corresp., }}{ }^{1}$, Tian Ya Li ${ }^{\text {Corresp. } 1}$ \\ ${ }^{1}$ College of Plant Protection, Shenyang Agricultural University, Shenyang, China \\ Corresponding Authors: Yuan Hu Xuan, Tian Ya Li \\ Email address: xuanyuanhu115@syau.edu.cn, litianya11@syau.edu.cn
}

Wheat stem rust, caused by Puccinia granimis f. sp. tritici, severely affects wheat production, but it has been effectively controlled in China since the 1970s. However, the appearance and spread of wheat stem rust races Ug99 (TTKSK, virulence to Sr31), TKTTF (virulence to SrTmp) and TTTTF (virulence to the cultivars carrying Sr9e and Sr13) have received attention. It is important to clarify the effectiveness of resistance genes in a timely manner, especially for the purpose of using new resistance genes in wheat cultivars for durable-resistance. However, little is known about the stem rust resistance genes present in widely used wheat cultivars from Gansu. This study aimed to determine the resistance level at the seedling stage of the main wheat cultivars in Gansu Province. A secondary objective was to assess the prevalence of Sr2, Sr24, Sr25, Sr26, Sr31, and Sr38 using molecular markers. The results of the present study indicated that 38 (50.7\%) wheat varieties displayed resistance to all the tested races of Puccinia graminis $\mathrm{f}$. sp. tritici. The molecular marker analysis showed that 13 out of 75 major wheat cultivars likely carried Sr2; 25 wheat cultivars likely carried Sr31; and 9 wheat cultivars likely carried Sr38. No cultivar was found to have Sr25 and Sr26, as expected. Surprisingly, no wheat cultivars carried Sr24. The wheat lines with known stem rust resistance genes could be used as donor parent for further breeding programs. 
1 Evaluation and identification of stem rust resistance genes $\operatorname{Sr} 2, \operatorname{Sr} 24, \operatorname{Sr} 25, \operatorname{Sr} 26, \operatorname{Sr} 31$ and

$2 \quad \mathbf{S r} 38$ in wheat lines from Gansu Province in China

3 Xiao Feng Xü, Dan Dan Li", Yang Liü, Yue Gao, Zi Yuan Wang, Yu Chen Ma, Shuo Yang,

4 Yuan Yin Cao, Yuan Hu Xuan*, Tian Ya Li*

5 College of Plant Protection, Shenyang Agricultural University, Shenyang, Liaoning, China

6 \#These authors contributed equally to this work.

$7 \quad *$ Corresponding authors

8 Phone/Fax: +86 248834 2056, litianya11@163.com (Tian Ya Li) or

9 Phone/Fax: +86 248834 2056, xuanyuanhu115@syau.edu.cn (Yuan Hu Xuan)

10 Abstract

11 Wheat stem rust, caused by Puccinia granimis f. sp. tritici, severely affects wheat production, but

12 it has been effectively controlled in China since the 1970s. However, the appearance and spread

13 of wheat stem rust races Ug99 (TTKSK, virulence to $S r 31$ ), TKTTF (virulence to $S r T m p$ ) and

14 TTTTF (virulence to the cultivars carrying $\mathrm{Sr} 9 \mathrm{e}$ and $\mathrm{Sr} 13$ ) have received attention. It is important

15 to clarify the effectiveness of resistance genes in a timely manner, especially for the purpose of

16 using new resistance genes in wheat cultivars for durable-resistance. However, little is known

17 about the stem rust resistance genes present in widely used wheat cultivars from Gansu. This

18 study aimed to determine the resistance level at the seedling stage of the main wheat cultivars in

19 Gansu Province. A secondary objective was to assess the prevalence of $S r 2, S r 24, S r 25, S r 26$,

20 Sr31, and Sr38 using molecular markers. The results of the present study indicated that 38

$21(50.7 \%)$ wheat varieties displayed resistance to all the tested races of Puccinia graminis f. sp.

22 tritici. The molecular marker analysis showed that 13 out of 75 major wheat cultivars likely 
23 carried $\operatorname{Sr} 2 ; 25$ wheat cultivars likely carried $\operatorname{Sr} 31$; and 9 wheat cultivars likely carried $\operatorname{Sr} 38$. No

24 cultivar was found to have $\operatorname{Sr} 25$ and $\operatorname{Sr} 26$, as expected. Surprisingly, no wheat cultivars carried

25 Sr24. The wheat lines with known stem rust resistance genes could be used as donor parent for

26 further breeding programs.

Introduction

29 Puccinia graminis Pers. f. sp. tritici Eriks. and E. Henn (Pgt) causes one of the most potentially

30 destructive wheat diseases, seriously threatening word grain production (Pardey et al., 2013).

31 Disease-resistance breeding to control wheat stem rust is economic, effective, and protective of

32 the environment, and has been proved to be the best control method by repeated practice

33 (Goutam et al., 2015). Wheat stem rust has been effectively controlled with the wide use of

34 resistance gene $\mathrm{Sr} 31$ from a 1BL/1RS wheat-rye chromosome arm translocation (Rouse et al.,

35 2012). However, a new race Ug99 virulent to $\operatorname{Sr} 31$ was identified in Uganda and classifed as

36 TTKS by the North American Nomenclature System of Pgt in 1999 (Pretorius et al., 2000). Ug99

37 has broad virulence, and mutates and spreads quickly. Since 1999, 13 variants of Ug99 have been

38 found in 13 countries (FAO, 2017). Recently, Ug99 has been monitored in Egypt, which is the

39 main wheat production area of the Middle East, revealing that its mode of spread is similar to that

40 of a virulent stripe rust pathogen race to $\operatorname{Yr} 9$ predicted by Geographic Information System of

41 CIMMYT (CIMMYT, 2007). Following the identification and spread of the Ug99 race group, a

42 new race TKTTF caused a wheat stem rust epidemic with an estimated 20,000 to 40,000 ha likely

43 planted to 'Digalu' (with resistance to Ug99 race group) in Southern Ethiopia during 2013-2014

44 (Olivera et al., 2015). Currently it has been confirmed in 11 countries, and given the rapid and 
45 destructive nature of race TKTTF, close monitoring of this race is advised - especially in

46 countries which have cultivars carrying the $\operatorname{SrTmp}$ resistance gene.

47 A new race TTTTF with virulence to $S r 9 e$ and $\operatorname{Sr} 13$ attacked thousands of hectares of durum

48 wheat in Sicily, Italy, in 2016, resulting in the largest burst of wheat stem rust in Europe since the

49 1950s (Bhattacharya, 2017). The large number of spores produced by TTTTF may continue the

50 epidemic in 2017. Moreover, the researchers from the Global Rust Research Center shared a

51 major concern in the warning report that TTTTF could infect not only durum wheat and bread

52 wheat but also dozens of laboratory-grown strains of wheat (FAO, 2017). In view of this, in

53 February 2017, 'Nature' highlighted the potential threat to European wheat production of this

54 race (Bhattacharya, 2017). Therefore, the spread of Ug99, TKTTF and TTTTF, and their variants,

55 threaten the wheat production safety in China.

56 Gansu Province, located in the northwest of China, plays a significant role in the epidemic and

57 spread of wheat stem rust in China (Cao, 1994). Resistance breeding for this disease has not been

58 a primary objective because it has been effectively controlled in China since the 1970s (Wu et al.,

59 2014). However, durable resistance to stem rust has been re-emphasized with the occurrence and

60 spread of new races of Pgt. It is necessary to analyze the resistance genes in wheat cultivars

61 (lines) from Gansu Province, and the information provided here will be important for developing

62 potentially durable combinations of stem rust resistance genes in cultivars.

\section{Materials and Methods}

\section{Wheat cultivars and near-isogenic lines}

65 A total of 75 tested wheat cultivars in Gansu Province were provided by Dr. Fangping Yang from

66 the Wheat Research Institute, Gansu Academy of Agricultural Sciences. 
67 Molecular markers linked to six $\operatorname{Sr}$ genes were tested: $\operatorname{Sr} 2, \operatorname{Sr} 24, \operatorname{Sr} 25, \operatorname{Sr} 26, \operatorname{Sr} 31$, and $\operatorname{Sr} 38$.

68 Near-isogenic lines carrying $45 S r$ genes were used to confirm the validity of these molecular

69 markers. The near-isogenic lines carrying these resistance genes were provided by Dr. Yue Jin

70 from USDA-ARS, Cereal Disease Laboratory, University of Minnesota, USA.

71 The tested Pgt races included the 21C3CTHTM, 21C3CFHQC, 34MKGQM, 34MKGSM,

72 34C3MTGQM and 34C3RTGQM (race 34C3MTGQM and 34C3RTGQM identified from the

73 alternative host Berberis). These races were named according to the methods described in a

74 published study ( $\mathrm{Li}$ et al., 2016b). The full names of the races and their virulence/avirulence

75 patterns are shown in Table 1 . They were isolated and identified by the Plant Immunity Institute,

76 Shenyang Agricultural University, China.

\section{Seedling resistance evaluation}

78 The cultivars were planted in porcelain pots with a 12-cm-diameter. Seven days later, the leaves

79 were moistened by water with $0.1 \%$ Tween 20 using an atomizer and then sprayed with $1 \mathrm{~g}$ of

80 fresh urediniospores and dried talc in a ratio of 1:20 (v:v). The inoculated seedlings were

81 transferred to a greenhouse with the temperature in a range of 18 to $22 \pm 1^{\circ} \mathrm{C}$. Three biological

82 replicates of the seedling assays were performed for each Pgt race. After 14 days of inoculation,

83 the infection types (ITs) were recorded using the 0-4 IT scale (Stakman, Stewart \& Loegering,

84 1962). ITs were then grouped into low ('0', ';', '1', '1+', '2', '2+', and X ) and high ('3-', '3',

85 ' $3+$ ', and '4') infection types. The ITs used in this study are shown in Fig. 1.

\section{DNA extraction}

87 DNA was extracted from young leaves of 10-day-old seedlings using a genomic DNA extraction 
88 kit (http://www.sangon.com/, China). The DNA quality was examined by $1.2 \%(\mathrm{w} / \mathrm{v})$ agarose

89 gels and DNA quantification was performed using the NanoDrop-1000 version 3.3.1

90 spectrophotometer.

91 Polymerase chain reaction (PCR)-specific primers were synthesized by Shanghai Biotech

92 Biotech Co., Ltd, China (Table 2). PCR amplifications were carried out in $25 \mu \mathrm{L}$ volume,

93 including $0.5 \mu \mathrm{L}$ of $10 \mathrm{mmol} \cdot \mathrm{L}^{-1}$ deoxyribonucleoside triphosphates, $2.5 \mu \mathrm{L}$ of $10 \times$ buffer $\left(\mathrm{Mg}^{2+}\right)$,

$940.2 \mu \mathrm{L}$ of $5 \mathrm{U} \cdot \mu \mathrm{L}^{-1}$ Taq polymerase, $1 \mu \mathrm{L}$ of $10 \mu \mathrm{mol} \cdot \mathrm{L}^{-1}$ of each primer, and $2 \mu \mathrm{L}$ of $30 \mathrm{ng} \cdot \mu \mathrm{L}^{-1}$

95 DNA. De-ionized water was used to achieve $25 \mu \mathrm{L}$ volume. Condition of PCR amplification were

96 as follows: $94^{\circ} \mathrm{C}$ for $4 \mathrm{~min}, 30$ cycles of $94^{\circ} \mathrm{C}$ for $45 \mathrm{~s}, 60^{\circ} \mathrm{C}$ for $45 \mathrm{~s}$, and $72^{\circ} \mathrm{C}$ for $1 \mathrm{~min}$,

97 followed by the final extension at $72^{\circ} \mathrm{C}$ for $8 \mathrm{~min}$; other specific conditions were as described in

98 previous studies (Table 1).

99 Results

100 Wheat seedling resistance

101 The resistance test results of 75 main wheat cultivars in Gansu to the races 21C3CTHTM,

102 21C3CFHQC, 34MKGQM, 34MKGSM, 34C3MTGQM, and 34C3RTGQM are shown in Table

103 3. Thirty-eight $(50.7 \%)$ of the 75 tested wheat cultivars showed different resistance levels (ITs

$1040, ; ; 1,1+$, and 2$)$ to the six races at the seedling stage (Table 4). The remaining $38(50.7 \%)$

105 wheat cultivars showed varying levels of susceptibility (ITs 3, 3-, 3+, and 4) (Table 3).

\section{Validity of the markers}


107 Six specific PCR markers closely linked with resistance genes $\operatorname{Sr} 2, \operatorname{Sr} 24, \operatorname{Sr} 25, \operatorname{Sr} 26, \operatorname{Sr} 31$, and

108 Sr38 were validated using 45 single differentials carrying known resistance genes. Table 5 shows

109 that these ten markers amplified only specific bands in the expected wheat genetic stocks. For

110 example, primer SCSS30.2576 amplified only 576-bp specific bands in Siouxland, Sisson,

$111 \mathrm{Sr} 31 / 6 * \mathrm{LMPG}$, and Federation*4/Kavl, while in other wheat lines without $\operatorname{Sr} 31$, no bands were

112 amplified, indicating that these markers are able to be well applied for the molecular detection of

113 the six resistance genes.

\section{Sr2 screening}

115 A DNA marker was developed to accurately predict $S r 2$ in diverse wheat germplasm for the

116 partial resistance of $S r 2$ is very difficult to screen under field conditions (Mago et al., 2011). Two

117 markers, $\mathrm{Xgwm} 533$ and $\operatorname{csSr} 2$, were used to detect $\mathrm{Sr} 2$ in wheat cultivars of Gansu Province. A

118 specific PCR band with 120-bp in size was amplified with marker Xgwm533, but no PCR product

119 was amplified using marker $c s S r 2$ in Hope with $S r 2$. In this study, a similar 120-bp band was

120 detected in the 13 cultivars, indicating that these cultivars carried $\mathrm{Sr} 2$ (Table 6).

\section{Sr24 screening}

122 Two markers, $\operatorname{Sr} 24 \# 12$ and $\operatorname{Sr} 24 \# 50$, were developed to detect $S r 24$, located on chromosome 3DL

123 in Agent- or 1BS in Amigo-derived lines (Mago et al., 2005). These two markers were applied to

124 detect $\operatorname{Sr} 24$ existence in the 75 major wheat cultivars (lines) of Gansu Province in this study. The

125 results showed that marker $\operatorname{Sr} 24 \# 12$ amplified a 500-bp specific band and marker $\operatorname{Sr} 24 \# 50$

126 amplified an approximately 200-bp specific band in the Sr24 control LcSr24Ag. No PCR

127 fragment was amplified in Little Club (LC) and the tested cultivars, indicating that these cultivars

128 lacked $\operatorname{Sr} 24$. 
129 Sr25 screening

130 Because of the resistance of $\operatorname{Sr} 25$ to the new race Ug99 and related strains, a dominant marker

$131 G b$ was developed for haplotyping Sr25, (FAO, 2017; Liu et al., 2010; Pretorius et al. 2000). The

132 presence of the marker was confirmed by detection of a 130-bp fragment. The PCR results

133 indicated that the 130-bp band was only amplified using the $S r 25$-positive line Agatha/9*LMPG

134 (monogenic Sr25) genomic DNA (Liu et al., 2010; Yu et al., 2010), but not with other cultivar

135 DNA samples, indicating that all 75 lines from Gansu Province examined lack $S r 25$.

\section{Sr26 screening}

137 Stem rust resistance gene Sr26 was transferred into the long arm of wheat chromosome 6A from

138 Thinopyrum ponticum (Mago et al., 2005). Although the cultivars carrying Sr26 displayed

139 resistance to all the dominant $P g t$ races in China, it is not utilized in wheat breeding. A dominant

140 STS marker $\operatorname{Sr} 26 \# 43$ was developed for detecting this wheat stem rust resistance gene and a 207-

141 bp band was amplified in wheat lines with $\operatorname{Sr} 26$ (Mago et al., 2005). Marker $\operatorname{Sr} 26 \# 43$ was used to

142 detect this fragment in tested wheat cultivars. No any visible band was detected, suggesting that

143 these varieties do not carry $\operatorname{Sr} 26$, as expected.

\section{Sr31 screening}

145 Two markers, SCSS30.2 $2_{576}$ and $\operatorname{Iag} 95$ linked to resistance gene $\operatorname{Sr} 31$, were used for detecting this

146 locus. SCSS30.2576 amplified a 576-bp fragment and marker Iag95 amplified an 1100-bp PCR

147 fragment in $S r 31$-carrying lines such as $S r 31 / 6^{*}$ LMPG and Siouxland (Fig. 2). No fragment was

148 amplified in the negative control LC. These two markers were used to detect $\mathrm{Sr} 31$ in the tested

149 cultivars. The result showed that these two fragments were detected in the 25 tested cultivars

150 (Table 6). 


\section{$151 \quad$ Sr38 screening}

152 The $\operatorname{Lr} 37-\operatorname{Sr} 38-\operatorname{Yr} 17$ rust resistance gene cluster was transferred to the short arm of bread wheat

153 chromosome 2AS from a segment of Triticum ventricosum (Tausch) Cess. chromosome 2NS

154 (Helguera et al., 2003). The 2NS-specific primer VENTRIUP-LN2 and 2AS-specific primer

155 URIC-LN2 were developed to detect this rust resistance gene cluster in commercial wheat

156 cultivars and 262-bp and 285-bp PCR products were amplified in wheat line carrying Lr37-Sr38-

157 Yr17, whereas none of these amplification products were found in negative control LC (without

158 Lr37-Sr38-Yr17). In this study, both 262-bp and 285-bp PCR fragments were amplified in nine

159 wheat cultivars, suggesting that these wheat cultivars carried $\operatorname{Sr} 38$ (Table 6).

160 Discussion

161 The broad-spectrum wheat stem rust resistance gene $\mathrm{Sr} 2$ confers adult plant resistance to stem

162 rust and is located on chromosome arm 3BS. It originated in tetraploid Yaroslav emmer $(T$.

163 dicoccum) and later was transferred to the susceptible bread wheat 'Marquis' in the 1920s

164 (McFadden, 1930). Several varieties with Sr2 were cultivated worldwide (Singh et al., 2011).

165 Markers Xgwm533 and csSr2 were used to detect Sr2 in wheat cultivars from Gansu. However,

166 marker csSr2 failed to predict Sr2. Only marker Xgwm533 amplified a 120-bp band in the

167 positive control and 13 tested cultivars, but the 120-bp band also occurred in many North

168 American and CIMMYT lines which are considered not to have $S r 2$. Therefore, it is difficult to

169 conclude that all the accessions that showed a 120-bp fragment size for this marker carry $\operatorname{Sr} 2$.

170 The stem rust resistance gene $\mathrm{Sr} 24$ is completely associated with leaf rust resistance

171 gene $\operatorname{Lr} 24$. It has been widely used in wheat breeding programs worldwide, since it was

172 introgressed into wheat lines (McIntosh, Wellings \& Park, 1995). Gene Sr24 was ineffective to 
173 some variants of Ug99 but is effective to the new races TKTTF, TTTTF, and many Pgt races in

174 China (Bhattacharya, 2017; Han, Cao \& Sun, 2010). Therefore, two markers, Sr24\#12 and

175 Sr24\#50, developed by Mago et al. (2005) were used to detect the gene in Gansu wheat cultivars

176 in this study. Surprisingly, no wheat cultivars carried this gene. However, it is reported that

177 Chinese wheat cultivars in other provinces carry Sr24 (Cao et al., 2007; Li et al., 2016b).

178 Wheat plants carrying stem rust resistance gene $\operatorname{Sr} 25$ were susceptible to several strains of

179 Chinese Pgt races (Cao et al., 2007). Sr25 and its linked leaf rust resistance gene $\operatorname{Lr} 19$, were

180 transferred into wheat, and observed its existence in the long arm to wheat chromosome 7D and

181 7A from Thinpyrum ponticum (Friebe et al., 1994; Zhang et al., 2005). The use of Sr25-Lr19 was

182 initially limited because of linkage with another Th. ponticum derived gene producing

183 undesirably yellow flour. It has been further backcrossed into the Australian and CIMMYT wheat

184 backgrounds with the mutant line (which contains Sr25-Lr19), but with white flour (Bariana et

185 al., 2007; Knott, 1980). The use of this gene in wheat programs are increasing for its resistance to

186 new races TTTTF and Ug99 race group, having potential yield increases under irrigated

187 conditions (FAO, 2017; Liu et al., 2010; Monneveux et al., 2003; Singh et al., 1998). In this

188 study, 75 wheat varieties from Gansu Province were examined for presence of marker Gb. The

189 result showed that all 75 wheat varieties lack $S r 25$.

190 In Australia, Sr26 has been released in the cultivar Eagle since 1971 (Martin, 1971). Later,

191 other major cultivars including Flinders, Harrier, Kite, Takari, and Sunelg, were cultivated. Lines

192 containing the $\operatorname{Sr} 26$ fragment are resistant to new stem rust pathogen races such as $\mathrm{Ug} 99$ and its

193 associated strains. None of the cultivars had $S r 26$ in the present study, as expected, and similar

194 results were observed in our previous study (Li et al., 2016a). 
195 The stem rust resistance gene $\operatorname{Sr} 31$ on $1 \mathrm{BL} / 1 \mathrm{RS}$ was transferred into the bread wheat from

196 'Petkus' rye (Graybosch, 2001). Since then a higher number of wheat cultivars carrying $\operatorname{Sr} 31$

197 have been released in global wheat breeding (Das et al., 2006). It is reported that more than 60\%

$198\left(1.3 \times 107 \mathrm{hm}^{2}\right)$ of the total wheat planting areas carried this translocation in China (Jiang et al.,

199 2007). Although the gene is ineffective to Ug99 and related variants, it is also an effective gene

200 against all Pgt races in China and the new races TKTTF and TTTTF. Molecular marker detection

201 showed that 25 wheat cultivars carried $\operatorname{Sr} 31$. All these cultivars (lines) produced resistance ITs $(0$,

$202 ; ; ; 1,1+$, and 2) to all tested Pgt races, as expected. Moreover, pedigree tracking indicated that

203 resistant materials carrying the $1 \mathrm{BL} / 1 \mathrm{RS}$ translocation such as 'Kavkaz' and 'Rye' were widely

204 used in wheat breeding in Gansu Province, revealing the origin of Sr31 in these wheat varieties.

205 Rust resistance gene cluster $\operatorname{Yr} 17-\operatorname{Lr} 37-\operatorname{Sr} 38$ was initially transferred into the winter bread

206 wheat line 'VPM1' from T. ventricosum and was located in a 2NS/2AS translocation (Bariana \&

207 McIntosh, 1993; Cao et al., 2007; Maia, 1967). PCR assays using restriction fragment length

208 marker $c M W G 682$ were developed for selecting the 2NS/2AS translocation in wheat cultivars

209 (Helguera et al., 2003). Sr38 became susceptible to new races related to Ug99 but no virulent Pgt

210 race to $\operatorname{Sr} 38$ has been found in China. The results showed that nine wheat cultivars carried the

211 gene cluster. The resistance of these cultivars against the tested Pgt races might be attributed to

212 this gene.

213 Conclusion

214 Breeding resistant cultivars is an economic and effective way to protect wheat from disease. The

215 development of molecular technology facilitated the identification and utilization of molecular

216 markers for durable resistance breeding, leading to increased crop production. The molecular 
217 markers associated with $\operatorname{Sr} 2, \operatorname{Sr} 24, \operatorname{Sr} 25, \operatorname{Sr} 26, \operatorname{Sr} 31$, and $\operatorname{Sr} 38$ were used to detect the occurrence

218 of these genes in 75 major wheat cultivars (lines) in Gansu Province in this study. The results

219 showed that 35 tested cultivars might carry one of these genes. This information can be used in

220 breeding for stem rust resistance in the future..

221 Acknowledgments

222 We appreciate very much Dr. Fangping Yang at Wheat Research Institute, Gansu Academy of

223 Agricultural Sciences for providing the wheat cultivars.

225 Reference

226 Bariana HS, Brown GN, Bansal UK, Miah H, Standen GE, and Lu M. 2007. Breeding triple rust

227 resistant wheat cultivars for Australia using conventional and marker-assisted selection 228 technologies. Australian Journal of Agricutural Research 58:576-587.

229 Bariana HS, and McIntosh RA. 1993. Cytogenetic studies in wheat XV. Location of rust 230 resistance genes in VPM1 and their genetic linkage with other disease resistance genes in 231 chromosome 2A. Genome 36:476-482.

232 Bhattacharya S. 2017. Deadly new wheat disease threatens Europe's crops. Nature 542:145-146.

233 Cao SQ, Zhang B, Li MJ, Xu SC, Luo HS, Jin SL, Jia QZ, Huang J, Jin AM, and Shuang XW.

234 2011. Postulation of stripe rust resistance genes and analysis of adult resistance in 50 wheat

235 varieties (lines) in Gansu Province. Acta Agronomica Sinica 37:1360-1371.

236 Cao YY. 1994. On epiphytotic pattern, long dispersion of Puccinia graminis f. sp. tritici and its

237 gene control through systematic engineering in China (in Chinese). D. Phil. Thesis, Shenyang 238 Agricultural University. 
239 Cao YY, Han JD, Zhu GQ, and Zhang L. 2007. Ug99, a new virulent race of Puccinia graminis f.

240 sp. tritici, and its effect on China. Plant Protection 33:86-89 (in Chinese).

241 CIMMYT. 2007. Dangerous wheat disease jumps Red Sea-devasta-ring fungal pathogen spreads

242 from Eastern Africa to Yemen, following path scientists predicted. Available at 243 http:\|huliq.coin.

244 Das BK, Saini A, Bhagwat SG, and Jawali N. 2006. Development of SCAR markers for

245 identification of stem rust resistance gene $S r 31$ in the homozygous or heterozygous condition

246 in bread wheat. Plant Breeding 125:544-549.

247 FAO. 2017. Spread of damaging wheat rust continues: new races found in Europe, Africa, Central

248 Asia. 3 February. Available at http://www.fao.org/news/story/en/ item/46946 7/icode/.

249 Friebe B, Jiang J, Knott DR, and Gill BS. 1994. Compensation indexes of radiation induced

250 wheat Agropyron-elongatum translocations conferring resistance to leaf rust and stemrust.

$251 \quad$ Crop Science 34:400-404.

252 Goutam U, Kukreja S, Yadav R, Salaria N, Thakur K, and Goya AK. 2015. Recent trends and 253 perspectives of molecular markers against fungal diseases in wheat. Frontiers in Micbiology $254 \quad 6: 861$.

255 Graybosch RA. 2001. Uneasy unions: Quality effects of rye chromatin transfers to wheat. $256 \quad$ Journal of Cereal Science 33:3-16.

257 Han JD, Cao YY, and Sun ZG. 2010. 2007-2008 Race dynamics of Puccinia graminis f. sp. tritici 258 in China and the virulence of CIMMYT wheat germplasm resistant to Ug99. Journal of 259 Triticeae Crops 30:163-166 (in Chinese).

260 Hayden MJ, Kuchel H, and Chalmers KJ. 2004. Sequence tagged microsatellites for the 
261 Xgwm533 locus provide new diagnostic markers to select for the presence of stem rust

262 resistance gene $S r 2$ in bread wheat (Triticum aestivum L.). Theoretical and Applied Genetics

263 109: 1641-1647.

264 Helguera M, Khan IA, Kolmer J, Lijavetzky D, Zhong-qi L, and Dubcovsky J. 2003. PCR assays

265 for the $\operatorname{Lr} 37-\mathrm{Yr} 17-\mathrm{Sr} 38$ cluster of rust resistance genes and their use to develop isogenic hard

266 red spring wheat lines. Crop Science 43:1839-1847.

267 Jiang YY, Chen WQ, Zhao ZH, and Zeng J. 2007. Threat of new wheat stem rust race Ug99 to

268 wheat production in China and countermeasure. China Plant Protection 27:14-16.

269 Knott DR. 1980. Mutation of a gene for yellow pigment linked to Lr19 in wheat. Canada Journal

270 of Genetics and Cytology 22:651-654.

271 Li TY, Cao YY, Wu XX, Xu XF, and Wang WL. 2016a. Seedling resistance to stem rust and

272 molecular marker analysis of resistance genes in wheat cultivars of Yunnan, China. Plos One

273 11:e0165640.

274 Li TY, Wu XX, Xu XF, Wang WL, and Cao YY. 2016b. Postulation of seedling stem rust

275 resistance genes of Yunnan wheat cultivars in China. Plant Protection Science 4:242-249.

276 Liu S, Yu LX, Singh RP, Jin Y, Sorrells ME, and Anderson JA. 2010. Diagnostic and co-dominant

277 PCR markers for wheat stem rust resistance genes Sr25 and Sr26. Theoretiacl and Applied

278 Genetics 120:691-697.

279 Mago R, Verlin D, Zhang P, Bansal U, Bariana H, Jin Y, Ellis J, Hoxha S, and Dundas I. 2013.

280 Development of wheat-Aegilops speltoides recombinants and simple PCR-based markers for

281 Sr32 and a new stem rust resistance gene on the 2 s\#1 chromosome. Theoretical and Applied

282 Genetics 126:2943-2955. 
283 Mago R, Bariana HS, Dundas IS, Spielmeyer W, Lawrence GJ, Pryor AJ, and Ellis JG. 2005.

284 Development of PCR markers for the selection of wheat stem rust resistance genes $\operatorname{Sr} 24$ and 285 Sr26 in diverse wheat germplasm. Theoretical and Applied Genetics 111:496-504.

286 Mago R, Brown-Guedira G, Dreisigacker S, Breen J, Jin Y, Singh R, Appels R, Lagudah ES, Ellis

287 J, and Spielmeyer W. 2011. An accurate DNA marker assay for stem rust resistance gene $S r 2$ in 288 wheat. Theoretical and Applied Genetics 122:735-744.

289 Mago R, Spielmeyer W, Lawrence GJ, Lagudah ES, Ellis JG, and PryorA. 2002. Identification 290 and mapping of molecular markers linked to rust resistance genes located on chromosome 1RS 291 of rye using wheat-rye translocation lines. Theoretical and Applied Genetics 104:1317-1324.

292 Maia N. 1967. Obtention des bles tendres resistants au pietin-verse par croisements 293 interspecifiques bles $\times$ Aegilops. Canada Research Academy Agriculture 53:149-154.

294 Martin RH. 1971. Eagle-a new wheat variety. Agricultural Gaz NSW 82:206-207.

295 McFadden ES. 1930. A successful transfer of emmer characters to vulgare wheat. Agronomy

296 Journal 22:1020-1034

297 McIntosh RA, Wellings CR, and Park RF. 1995. Wheat rusts, an atlas of resistance genes.

298 CSIRO, Melbourne.

299 Monneveux P, Reynolds MP, Aguilar JG, and Singh RP. 2003. Effects of the 7DL.7Ag 300 translocation from Lophopyrum elongatum on wheat yield and related morphophysiological 301 traits under different environments. Plant Breeding 122:379-384

302 Olivera P, Newcomb M, Szabo LJ, Rouse M, Johnson J, Gale S, Luster DG, Hodson D, Cox JA, 303 Burgin L, Hort M, Gilligan CA, Patpour M, Justesen AF, Hovmøller MS, Woldeab G, Hailu 304 E, Hundie B, Tadesse K, Pumphrey M, Singh RP, and Jin Y. 2015. Phenotypic and genotypic 
305 characterization of race TKTTF of Puccinia graminis f. sp. tritici that caused a wheat stem 306 rust Epidemic in Southern Ethiopia in 2013-14. Phytopathology 105:917-928.

307 Pardey PG, Beddow JM, Kriticos DJ, Hurley TM, Park RF, Duveiller E, Sutherst RW, Burdon JJ, 308 and Hodson D. 2013. Right-sizing stem-rust research. Science 340:147-148.

309 Pretorius ZA, Singh RP, Wagoire WW, and Payne TS. 2000. Detection of virulence to wheat stem 310 rust resistance gene Sr31 in Puccinia graminis f. sp. tritici in Uganda. Plant Disease 84:203.

311 Rouse MN, Nava IC, Chao S, Anderson JA, and Jin Y. 2012. Identification of markers linked to

312 the race Ug99 effective stem rust resistance gene Sr28 in wheat (Triticum aestivum L.). 313 Theoretical and Applied Genetics 125:877-885.

314 Seah S, Bariana H, Jahier J, Sivasithamparam K, and Lagudah ES. 2012. The introgressed 315 segment carrying rust resistance genes $\operatorname{Yr} 17, \operatorname{Lr} 37$ and $\operatorname{Sr} 38$ in wheat can be assayed by a 316 cloned disease resistance gene-like sequence. Theoretical and Applied Genetics 102:600-605.

317 Singh RP, Huerta-Espino J, Bhavani S, Herrera-Foessel SA. Sing D, Sing PK, Velu G, Masson

318 RE, Jin Y, Njau P, and Crossa J. 2011. Race non-specific resistance to rust diseases in 319 CIMMYT spring wheats. Euphytica 179: 175-186.

320 Singh RP, Huerta-Espino J, Rajaram S, and Crossa J. 1998. Agronomic effects from chromosome 321 translocations 7DL.7Ag and 1BL.1RS in spring wheat. Crop Science 38:27-33

322 Stakman EC, Stewart DM, and Loegering WQ. 1962. Identification of physiologic races of 323 Puccinia graminis var. tritici. US Department of Agric ARSE-617, p53.

324 The TT, Gupta RB, Dyck PL, Applels R, Hohmann U, and McIntosh RA. 1992. Characterization 325 of stem rust resistance derivatives of wheat variety Amigo. Euphytica 58:245-252.

326 Wu XX, Li TY, Chen S, Wang GQ, Cao YY, and Ma SL. 2014. Stem rust resistance evaluation 
327 and Ug99-resistance gene detection of 139 wheat cultivars. Scientia Agricultural Sinica 328 47:4618-4626 (in Chinese).

329 Yu L, Liu S, Anderson JA, Singh RP, Jin Y, Dubcovsky J, Gina BJ, Bhavani S, Morgounov A, He 330 Z, Huerta-Espino J, and Sorrells ME. 2010. Haplotype diversity of stem rust resistance loci in 331 uncharacterized wheat lines. Molecular Breeding 26:667-680.

332 Zhang W, Lukaszewski AJ, Kolmer J, Soria MA, Goyal S, and Dubcovsky J. 2005. Molecular characterization 333 of durum and common wheat recombinant lines carrying leaf rust resistance ( $\operatorname{rr} 19)$ and yellow pigment (Y) 334 genes from Lophopyrumponticum. Theoretical and Applied Genetics 111:573-582.

335 
Figure 1

Infection types used in this study.
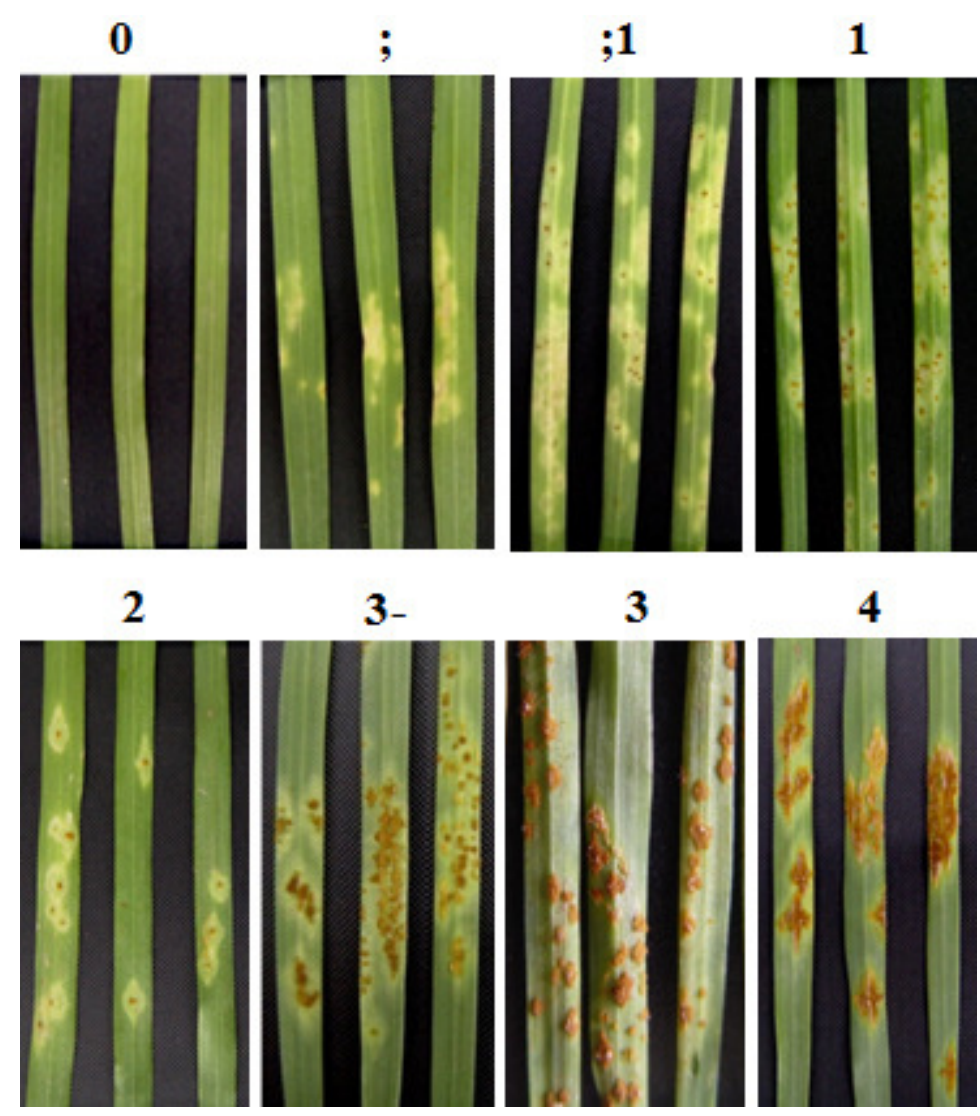

3-

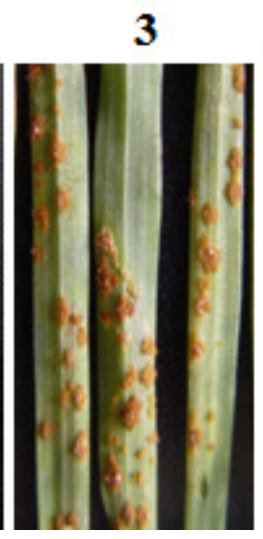

4

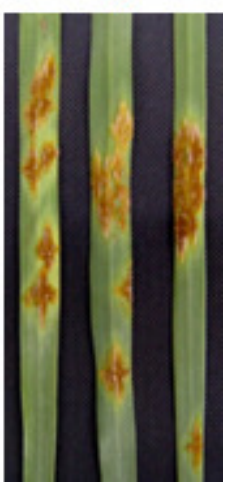




\section{Figure 2}

Amplification result for some of the tested wheat varieties of wheat varieties with SCSS30.2 576 and lag95.

Lane 1-11, Monogenic Sr31, Little Club, Wuchun 7, Dingxi 41, Longchun 31, Longchun 22, Ganchun 25, Longchun 25, Longchun 23, Longchun 26, Ganchun 24, Yinchun 9, 'M' indicates 2000 bp DNA ladder and black arrow indicates the position of the specific band.

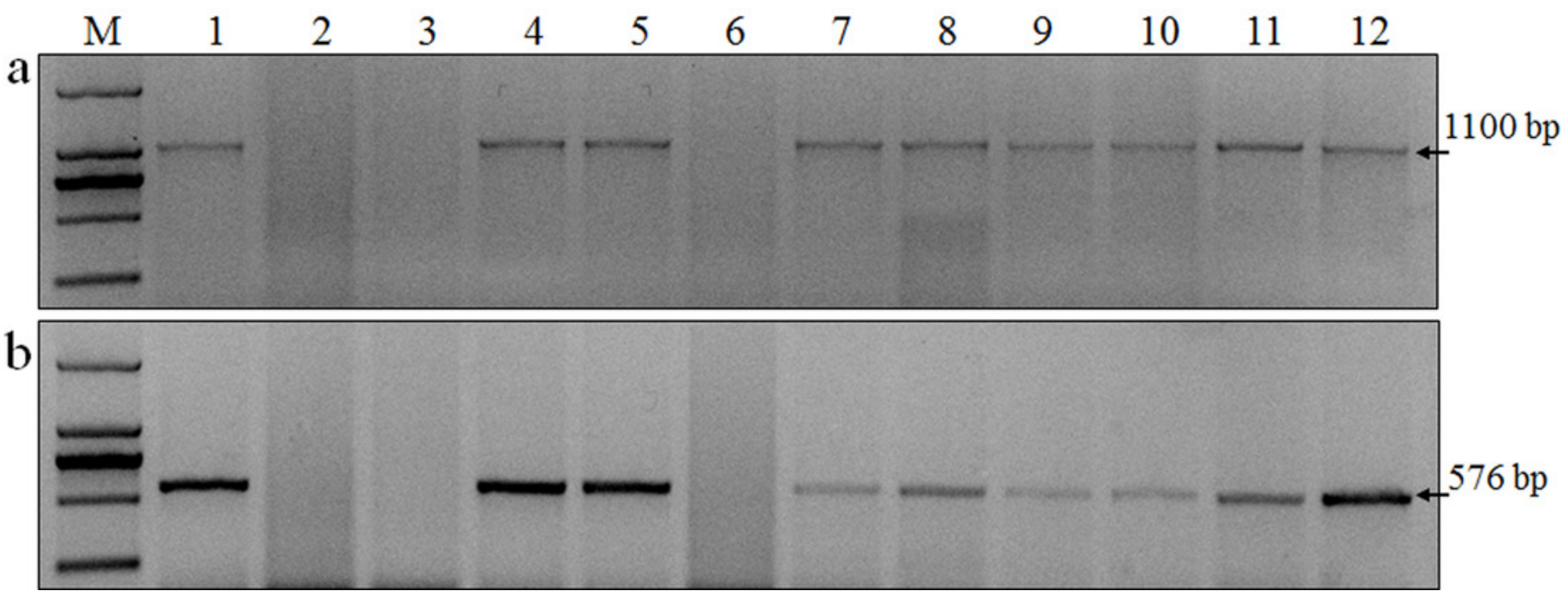




\section{Table 1 (on next page)}

Virulence/avirulence patterns of six races of $P$. graminis f. sp. tritici 


\begin{tabular}{|c|c|c|}
\hline Race & Ineffective $S r$ genes & Effective $S r$ genes \\
\hline 21С3СТНТМ & $\begin{array}{l}6,7 b, 8 a, 9 a, 9 b, 9 d, 9 f, 9 g, 10,11,12,13,14,15,16,17,18 \\
24,28,29,34,35, T m p, M c N\end{array}$ & $\begin{array}{l}5,9 e, 19,20,21,22,23,25,26,27,30,31,32,33,36,37, \\
38,47\end{array}$ \\
\hline 21C3CFHQC & $\begin{array}{l}7 b, 8 a, 9 a, 9 b, 9 d, 9 f, 9 g, 12,13,14,15,16,17,18,28,29,34 \\
35, M c N\end{array}$ & $\begin{array}{l}5,6,9 e, 10,11,19,20,21,22,23,24,25,26,27,30,31, \\
32,33,36,37,38,47, \text { Tmp }\end{array}$ \\
\hline 34MKGQM & $\begin{array}{l}5,6,7 b, 8 a, 9 a, 9 b, 9 d, 9 f, 9 g, 12,15,16,20,24,27,28,29, \\
M c N\end{array}$ & $\begin{array}{l}9 e, 10,11,13,14,17,18,19,21,22,23,25,26,30,31,32, \\
33,34,35,36,37,38,47, \text { Tmp }\end{array}$ \\
\hline 34MKGSM & $\begin{array}{l}5,6,7 b, 8 a, 9 a, 9 b, 9 d, 9 f, 9 g, 10,12,15,16,20,24,27,28 \\
29, M c N\end{array}$ & $\begin{array}{l}9 e, 11,13,14,17,18,19,21,22,23,25,26,30,31,32,33, \\
34,35,36,37,38,47, \text { Tmp }\end{array}$ \\
\hline 34C3RKGQM & $\begin{array}{l}5,6,7 b, 8 a, 9 a, 9 b, 9 d, 9 f, 9 g, 12,16,19,21,23,24,27,28 \\
29, M c N\end{array}$ & $\begin{array}{l}9 e, 10,11,13,14,15,17,18,20,22,25,26,30,31,32,33, \\
34,35,36,37,38,47, \text { Tmp }\end{array}$ \\
\hline 34C3MTGQM & $\begin{array}{l}7 b, 8 a, 9 a, 9 b, 9 d, 9 f, 9 g, 11,12,13,14,15,16,17,18,28,29 \\
34,35, M c N\end{array}$ & $\begin{array}{l}5,6,9 e, 10,19,20,21,22,23,24,25,26,27,30,31,32, \\
33,36,37,38,47, \text { Tmp }\end{array}$ \\
\hline
\end{tabular}

1 


\section{Table 2 (on next page)}

The markers linked to resistance genes $\operatorname{Sr} 2, \operatorname{Sr} 24, \operatorname{Sr} 26, \operatorname{Sr} 31$ and $\operatorname{Sr} 38$ with their forward and backward primers. 
1

\begin{tabular}{|c|c|c|c|c|}
\hline Genes & Marker & Forward primer & Reverse primer & References \\
\hline \multirow{2}{*}{$\operatorname{Sr} 2$} & Xgwm533 & 5'-GTTGCTTTAGGGGAAAAGCC & 5'-AAGGCGAATCAAACGGAATA & Hayden et al., 2004 \\
\hline & $\operatorname{csSr} 2$ & 5'-CAAGGGTTGCTAGGATTGGAAAAC & 5'-AGATAACTCTTATGATCTTACATTTTTCTG & Mago et al., 2011 \\
\hline \multirow{2}{*}{$\operatorname{Sr} 24$} & $\operatorname{Sr} 24 \# 12$ & 5'-CACCCGTGACATGCTCGTA & 5'-AACAGGAAATGAGCAACGATGT & Mago et al., 2005 \\
\hline & Sr24\#50 & 5'-CCCAGCATCGGTGAAAGAA & 5'-ATGCGGAGCCTTCACATTTT & Mago et al., 2005 \\
\hline $\operatorname{Sr} 25$ & $G b$ & 5'-CATCCTTGGGGACCTC & 5'-CCAGCTCGCATACATCCA & Liu er al., 2010 \\
\hline $\operatorname{Sr} 26$ & $\operatorname{Sr} 26 \# 43$ & 5'-AATCGTCCACATTGGCTTCT & 5'-CGCAACAAAATCATGCACTA & Mago et al., 2005 \\
\hline \multirow{2}{*}{$\operatorname{Sr} 31$} & $\operatorname{SCSS} 30.2_{576}$ & 5'-GTCCGACAATACGAACGATT & 5'-CCGACAATACGAACGCCTTG & Das et al., 2006 \\
\hline & Iag95 & 5'-CTCTGTGGATAGTTACTTGATCGA & 5'-CCTAGAACATGCATGGCTGTTACA & Mago et al., 2002 \\
\hline \multirow{2}{*}{$\operatorname{Sr} 38$} & VENTRIUP-LN2 & 5'-AGGGGCTACTGACCAAGGCT & 5'-TGCAGCTACAGCAGTATGTACACAAAA & Helguera et al., 2003 \\
\hline & URIC-LN2 & 5'-GGTCGCCCTGGCTTGCACCT & 5'-TGCAGCTACAGCAGTATGTACACAAAA & Helguera et al., 2003 \\
\hline
\end{tabular}

2 


\section{Table 3 (on next page)}

Resistant proportion of 75 wheat cultivars to six races of $P$. graminis f. sp. tritici 
1

\begin{tabular}{lcccc}
\hline \multirow{2}{*}{ Races } & \multicolumn{2}{c}{ Susceptible } & & \multicolumn{2}{c}{ Resistance } \\
\cline { 2 - 5 } & Number of cultivars & Percentage/\% & Number of cultivars & Percentage/\% \\
\hline 21 C3CTHTM & 28 & 37.3 & 47 & 62.7 \\
21C3CFHQC & 25 & 33.3 & 50 & 66.7 \\
34MKGQM & 30 & 40.0 & 45 & 60.0 \\
34MKGSM & 26 & 34.7 & 49 & 65.3 \\
34C3RKGQM & 26 & 34.7 & 49 & 65.3 \\
34C3MTGQM & 25 & 33.3 & 50 & 66.7 \\
All tested races & 37 & 49.3 & 38 & 50.7 \\
\hline
\end{tabular}

2 


\section{Table 4 (on next page)}

Seedling infection types produced by six races of $P$. graminis f. sp. tritici on 75 wheat cultivars (lines) 


\begin{tabular}{|c|c|c|c|c|c|c|c|}
\hline \multirow{2}{*}{ Cultivars(lines) } & \multirow{2}{*}{ Pedigree } & \multicolumn{6}{|c|}{ Infection types ${ }^{\mathrm{a}}$} \\
\hline & & 21C3CTHQM & 21C3CFHQC & $34 \mathrm{MKGQM}$ & 34MKGSM & 34C3RTGQM & 34C3MTGQM \\
\hline Ningchun 39 & Yong 833/Ningchu 4 & 0 & 1 & 0 & 1 & 0 & 0 \\
\hline Dingfeng 10 & Tal 73-3/Mota & 0 & 0 & 0 & 1 & 0 & ; \\
\hline Linmai 32 & Ganfu 92-310/Xianyang-dasui & 4 & 4 & 4 & $3-$ & 3 & 4 \\
\hline Wuchun8 & Shi 1269/Shi 1269 & $1+$ & 0 & $3-$ & 1 & 0 & 0 \\
\hline Wuchun 7 & Yong 434/Jian 94-114 & 4 & $3-$ & 4 & 1 & 4 & $3-$ \\
\hline Dingxi 41 & 8124-10/Dongxiang 77-011 & ; & 0 & 0 & ; & 0 & 0 \\
\hline Longchun 31 & Genic male sterility of Taigu & 0 & $; 1$ & 0 & 1 & 0 & ; \\
\hline Longchun 22 & $\mathrm{CHIL} / \mathrm{BUC}$ & 0 & 0 & 0 & 3 & 0 & 2 \\
\hline Ganchun 25 & $\begin{array}{l}\text { M34IBWSN-262/M34IBWSN-252// } \\
\text { Zhangchun 11/Yongliang } 4\end{array}$ & 0 & 0 & 0 & 0 & 0 & 0 \\
\hline Longchun 25 & Yong 1265/Corydon & ; & 1 & 2 & 0 & 2 & 0 \\
\hline Longchun 23 & Introduced from CIMMYT & 0 & 1 & 0 & $1+$ & 0 & ; \\
\hline Longchun 26 & Yong 3263/Gaoyuan 448 & 0 & 0 & 0 & 1 & 0 & ; \\
\hline Ganchun 24 & $\begin{array}{l}\text { Zhangchun11/93-7-31//23416-8-1//Aibai/ } \\
\text { Kavkaz }\end{array}$ & 0 & 2 & 0 & ; & 0 & ; \\
\hline Yinchun 9 & Dingxi 35/Xihan 1//Dingxi 37/9208 & 0 & 0 & 0 & 0 & 0 & 2 \\
\hline Longchun 28 & 8858-2/Longchun 8 & ; & 1 & 0 & 3 & ; & 3 \\
\hline Wuchun 5 & 7906/ROBLIN//21-27 & $1+$ & 1 & 3 & 4 & ; & $3-$ \\
\hline Ganchun 20 & $88-862 / 630$ & 4 & 4 & 4 & 4 & 4 & $3+$ \\
\hline Ningchun 4 & Sonora $64 /$ Hongtu & 4 & 4 & $3-$ & 4 & 4 & 4 \\
\hline Linmai 35 & Yong 2H15//Gui 86101/79531-1 & 4 & 4 & 4 & 4 & 4 & 1 \\
\hline Xihan 2 & 8917C/Qinmai 3/72114 & 4 & 4 & 4 & 3 & 2 & ; \\
\hline Dingxi 38 & RFMIII-101-A/Dingxi 32 & $; 1$ & 0 & 1 & 0 & 0 & 0 \\
\hline Ganchun 21 & $\begin{array}{l}\text { Aibai/Zhangchun 11//2014/82166-1- } \\
\text { 2//Zhangchun } 17\end{array}$ & 4 & 4 & 1 & 4 & 4 & ; \\
\hline Dingxi 40 & $8152-8 /$ Yong 257 & 4 & 3 & 4 & 1 & 4 & 4 \\
\hline Wuchun 4 & $\begin{array}{l}\text { 80-62- 3/7586//Rye//India Aisheng/Liaochun } \\
\text { 10/Paulin }\end{array}$ & 0 & 0 & 0 & 1 & 0 & 0 \\
\hline Wuchun 3 & Yi 5/Shi 857 & 4 & 4 & 4 & $3+$ & 4 & 3 \\
\hline Jinchun 5 & Shanqianhong/Funo & ; & ; & 0 & 2 & 0 & 1 \\
\hline Gansu 26 & Unknown & $1+$ & $; 1$ & 1 & 1 & 1 & 2 \\
\hline Linmai 33 & 92 Yuan 11/Guinong 20 & 1 & 1 & ; & 0 & 1 & ; \\
\hline Longchun 33 & Longchun 19/Longchun 23 & 4 & 1 & 3 & 1 & 4 & 0 \\
\hline Jiuchun 6 & Jiu 96159/Jiu 9061 & ; & 0 & 0 & 0 & $1+$ & 0 \\
\hline Longchun 27 & 8858-2/Longchun 8 & 1 & $1+$ & 1 & 1 & $; 1$ & 1 \\
\hline Linmai 34 & 94 Xuan 4149/Guinong 20//82316/Linmai 26 & 0 & 0 & 0 & 0 & 2 & ; \\
\hline Dingfeng 12 & Tal 73-3/Mota//Dingfeng 1 & 0 & $1+$ & 2 & 2 & 1 & $; 1$ \\
\hline Dingfeng 16 & $8447 / \mathrm{CMS} 420$ & 4 & 3 & 2 & 1 & 4 & ; \\
\hline Zhangchun 21 & Gaoyuan 602/I 97-2//Gaoyuan 602 & 1 & 1 & 0 & ; & $1+$ & 0 \\
\hline Wuchun 6 & $\begin{array}{l}\text { 80-62-3/Ningchun 4//Rye/India } \\
\text { Aisheng/Liaochun 10//Paulin }\end{array}$ & 0 & 0 & ; & 2 & 0 & $1-$ \\
\hline Lantian 23 & SXAF4-7/87-121 & $3+$ & ; & 4 & 1 & 0 & ; \\
\hline Lantian 19 & Mega/Lantian 10 & 4 & 4 & 4 & 4 & 4 & 4 \\
\hline Lantian 25 & 95-173-4/Baofeng 6 & $3+$ & 0 & 4 & 4 & 0 & 4 \\
\hline Lantian 13 & A21//832809/872121-7 & ; & 4 & 3 & 4 & 0 & 4 \\
\hline Xifeng 27 & 83183-1-3-1/CA837 & ; & 2 & 1 & $1+$ & ; & $1+$ \\
\hline Lantian 26 & Flansers/Lantian 10 & 0 & 2 & 1 & $1+$ & 1 & 1 \\
\hline Longjian 101 & $\begin{array}{l}\text { 85(1)F3 Xuan (2)-4/Shanhan 8968//85-173-12- } \\
2\end{array}$ & 4 & 1 & 4 & 4 & 4 & 4 \\
\hline
\end{tabular}




\begin{tabular}{|c|c|c|c|c|c|c|c|}
\hline Hangxuan 1 & Unknown & 0 & 0 & 0 & 0 & 0 & 0 \\
\hline Lantian 14 & Qingshang 895/Zhongliang 17 & 0 & $1+$ & 0 & 0 & 0 & ; \\
\hline Lantian 31 & Long Bow/Lantian 10 & 0 & 1 & $3-$ & 3 & 2 & 3 \\
\hline Pingliang 42 & tal Changwu 131/Pingliang 38/82(51) & $; 1$ & $3-$ & $3-$ & 2 & 4 & 3 \\
\hline Xifeng 20 & Xifeng 18/CA8055 & 1 & $3-$ & 2 & 2 & 1 & 1 \\
\hline Longyu 4 & Xifeng 20/Zhong 210 & 0 & 1 & 2 & 2 & 1 & 1 \\
\hline Changwu 131 & 7014-5/Zhongsu 68//F16-71 & 4 & 4 & 4 & 4 & 4 & 4 \\
\hline Zhongliang 18 & Kangyin 655/Elytrigia trichophora//Jingai 21 & 4 & 3 & 0 & 1 & 4 & 4 \\
\hline Zhongliang 22 & Zhong $_{5} / \mathrm{S}_{394} / /$ Xiannong 4 & 0 & 0 & $; 1$ & 1 & 0 & 0 \\
\hline Lantian 10 & Xifeng 16/Predgornajia/68286-0-1-1 & ; & 2 & 0 & 1 & 1 & 1 \\
\hline Tianxuan 39 & Unknown & 1 & $1+$ & $; 1$ & 0 & 0 & 1 \\
\hline Huandong 6 & Unknown & 4 & 0 & 4 & 0 & 4 & 3 \\
\hline Longjian 196 & 64035/Taiyuan 89/Qinnong 4 & 4 & 4 & 4 & 4 & 4 & 4 \\
\hline Lantian 30 & 95-111-3/Shan 167 & 1 & 2 & 2 & 3 & 1 & 2 \\
\hline $\begin{array}{l}\text { Longnan 2000-8- } \\
2-1\end{array}$ & Unknown & 0 & 1 & 0 & $; 1$ & 1 & 2 \\
\hline Longjian 301 & DW803/7992 & $1+$ & 1 & ; & $1+$ & 1 & 2 \\
\hline Longyu 2 & Longdong 3 号//82(348)/9002-1-1 & 0 & 1 & 1 & 1 & 1 & 1 \\
\hline Longjian P430 & Unknown & 0 & 1 & ; & 1 & 1 & 0 \\
\hline Longjian 103 & Longjian 127/Mo(W)697 & 4 & 4 & 4 & 2 & 4 & 2 \\
\hline Lantian 29 & $82 \mathrm{~F}-37 / 83-44-20 / / 8380$ & 4 & 3 & 4 & 4 & 4 & 3 \\
\hline Lan 092 & Unknown & 0 & 2 & $1-$ & 4 & 1 & 0 \\
\hline Qingnong 1 & $7084 / 2037$ & 4 & 4 & 4 & 3 & 4 & $3+$ \\
\hline Pingyuan 50 & Local cultivar & $3+$ & 4 & 4 & 4 & 4 & 4 \\
\hline Longyuan 034 & Unknown & 0 & 2 & 0 & $1+$ & 0 & 1 \\
\hline Lan 05-9-1-4 & Unknown & 4 & 4 & 4 & 2 & 4 & $3+$ \\
\hline Gandong 017 & Unknown & 0 & 2 & 2 & $; 1$ & 0 & 1 \\
\hline Longjian 19 & Jinan 2/Qinnong 4 & 4 & 3 & 4 & 3 & 4 & 4 \\
\hline Lantian 24 & 92R137/87-121-2 & 4 & 0 & 4 & 4 & 4 & 2 \\
\hline $863-13$ & Xiannong 4/Tianxuan 42 & 0 & 0 & 0 & 0 & 0 & 0 \\
\hline $01-426 \mathrm{e}-1$ & Unknown & $3+$ & 4 & 3 & 4 & 4 & 3 \\
\hline Tian 01-29 & Unknown & ; & 2 & 2 & 2 & ; & 2 \\
\hline Tian 01-104 & Unknown & 4 & 4 & 4 & $3-$ & 4 & 4 \\
\hline
\end{tabular}

2 a Infection types (ITs): are based on a 0-to-4 scale where ITs of $0, ;, 1$, and 2 are indicative of a resistant (low) response and ITs 3 of 3 or 4 of a susceptible (high) response; Symbols + and - indicate slightly larger and smaller pustule sizes, respectively 4 (Stakman, Stewart \& Loegering, 1962). 


\section{Table 5 (on next page)}

Amplification results for the known Sr genes by markers 


\begin{tabular}{|c|c|c|c|c|c|c|c|c|c|c|c|c|}
\hline \multirow[t]{3}{*}{ Line } & \multirow[t]{3}{*}{ Sr Gene } & \multirow[t]{3}{*}{ Source } & \multirow[t]{2}{*}{$S r 2$} & \multirow{2}{*}{$\begin{array}{c}S r \\
2\end{array}$} & \multirow[t]{2}{*}{$\operatorname{Sr} 24$} & \multirow[t]{2}{*}{$\operatorname{Sr} 24$} & \multirow[t]{2}{*}{$\operatorname{Sr} 25$} & \multirow[t]{2}{*}{$\operatorname{Sr} 26$} & \multirow[t]{2}{*}{$\operatorname{Sr} 31$} & \multirow{2}{*}{$\begin{array}{l}S r \\
31\end{array}$} & \multirow[t]{2}{*}{$\operatorname{Sr} 38$} & \multirow[t]{2}{*}{ Sr38 } \\
\hline & & & & & & & & & & & & \\
\hline & & & Xgwm5 & cs & $\operatorname{Sr} 24$ & Sr24\#50 & $G b$ & $\operatorname{Sr} 26$ & $\operatorname{SCSS} 30.2$ & Iag & VENTRI & URIC- \\
\hline ICre_d & 5 & $11 \Delta$ hardoon & $-a^{a}$ & - & - & - & - & - & - & - & - & - \\
\hline CnS $\mathrm{T}$ mono der & 21 & 11Aberdeen & - & - & - & - & - & - & - & - & - & - \\
\hline Varnctine & $o_{0}$ & $11 \Delta$ hardoon & - & - & - & - & - & - & - & - & - & - \\
\hline ISr7h_Ra & $7 h$ & $11 \Delta$ herdeen & - & - & - & - & - & - & - & - & - & - \\
\hline IS 11 - R a & 11 & $11 \mathrm{SH}$ & - & - & - & - & - & - & - & - & - & - \\
\hline ICr-Pa & $\kappa$ & 11 तH & - & - & - & - & - & - & - & - & - & - \\
\hline $\mathrm{ICr} \mathrm{O}_{-} \mathrm{D}_{2}$ & $8 n$ & $11 \Delta$ hardoon & - & - & - & - & - & - & - & - & - & - \\
\hline $\mathrm{rnCrOr}$ & $O_{r}$ & 1n $\Delta$ hardaon & - & - & - & - & - & - & - & - & - & - \\
\hline $\mathrm{x} / 2601 \mathrm{CrTt}_{-} 1$ & 26 & 11 तH & - & - & - & - & - & - & - & - & - & - \\
\hline W/9601 CrOh & oh & $11 \Delta$ hardaan & - & - & - & - & - & - & - & - & - & - \\
\hline $\mathrm{RtC} 3 \cap \mathrm{W} / \mathrm{ct}$ & $2 n$ & $11 \Delta$ hardoon & - & - & - & - & - & - & - & - & - & - \\
\hline Comhination V/II & $17+12$ & $11 \Delta$ hardaon & - & - & - & - & - & - & - & - & - & - \\
\hline $\mathrm{ICrO}_{2} \mathrm{Ra}$ & $o_{r}$ & $11 \Delta$ hordaon & - & - & - & - & - & - & - & - & - & - \\
\hline ICrOA_Ra & $O d$ & $11 \Delta$ hardaon & - & - & - & - & - & - & - & - & - & - \\
\hline W/วk01 $\mathrm{Cr} 1 \mathrm{n}$ & $1 n$ & $11 \Delta$ hardaon & - & - & - & - & - & - & - & - & - & - \\
\hline rnclerTmn & $T_{m n}$ & $11 \Delta$ hardaon & - & - & - & - & - & - & - & - & - & - \\
\hline $\mathrm{I} r \mathrm{Cr} \cap \Delta \Delta r$ & 91 & $11 \Delta$ hardaon & - & - & + & + & - & - & - & - & - & - \\
\hline $\mathrm{Cr} 21 / 6 * \mathrm{I} M \mathrm{MP}$ & 21 & $11 \Delta$ hardoan & - & - & - & - & - & - & + & + & - & - \\
\hline Trident & 38 & $11 \Delta$ hardean & - & - & - & - & - & - & - & - & + & + \\
\hline MoNair 701 & $M \cap \cap N$ & Sriffar 9010 & - & - & - & - & - & - & - & - & - & - \\
\hline$I$ ine $F$ & - & $n O \Delta R$ & - & - & - & - & - & - & - & - & - & - \\
\hline$\Delta \sim \mathrm{ma}$ & $O_{r}$ & $n o \Delta R$ & - & - & - & - & - & - & - & - & - & - \\
\hline Cinuvland & $71+21$ & $2 n 11$ & - & - & + & + & - & - & + & + & - & - \\
\hline Siconn & $21+26$ & Friffor $) \cap 10$ & - & - & - & - & - & - & + & + & - & - \\
\hline $\mathrm{C} w / \mathrm{Cr})>\mathrm{TR}$ & 3 & 17 今H & - & - & - & - & - & - & - & - & - & - \\
\hline$\Delta$ matha/O $*$ I MDS & 25 & $n \& \Delta R$ & - & - & - & - & + & - & - & - & - & - \\
\hline Facrla & 36 & $1 \cap \Delta \mathrm{R}$ & - & - & - & - & - & + & - & - & - & - \\
\hline $72 \supset 142,1 / 0 * \mathrm{I}$ м & 97 & $n \& \Delta R$ & - & - & - & - & - & - & - & - & - & - \\
\hline Fodaration $* \Lambda / K$ av 1 & 21 & $1 \cap \Delta \mathrm{R}$ & - & - & - & - & - & - & + & + & - & - \\
\hline FR 5155 & 27 & $1 \cap \Delta \mathrm{R}$ & - & - & - & - & - & - & - & - & - & - \\
\hline 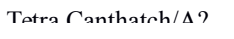 & 22 & $n \circ \Delta R$ & - & - & - & - & - & - & - & - & - & - \\
\hline 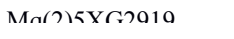 & 25 & $1 \cap \Delta \mathrm{R}$ & - & - & - & - & - & - & - & - & - & - \\
\hline$x / 2562$ & 27 & no $\Delta$ hard & - & - & - & - & - & - & - & - & - & - \\
\hline I Gก8? & 20 & $1 \cap \Delta \mathrm{R}$ & - & - & - & - & - & - & - & - & - & - \\
\hline I $6 \cap 88$ & $\Delta n$ & $1 \cap \Delta \mathrm{R}$ & - & - & - & - & - & - & - & - & - & - \\
\hline$T \Delta F ?$ & 11 & $1 \cap \Delta \mathrm{R}$ & - & - & - & - & - & - & - & - & - & - \\
\hline$n \Delta \mathrm{C} 15$ & 17 & $1 \cap \Delta \mathrm{R}$ & - & - & - & - & - & - & - & - & - & - \\
\hline Catur & Satu & no $\Delta$ hord & - & - & - & - & - & - & - & - & - & - \\
\hline TAM 107_1 & $141 R$ & 17 СH & - & - & - & - & - & - & - & - & - & - \\
\hline Fad*2/Rahn*? $1 \mathrm{RI}$ & $P$ & $1 \cap \Delta \mathrm{R}$ & - & - & - & - & - & - & - & - & - & - \\
\hline Inmilln & $0 \times 17$ & norH & - & - & - & - & - & - & - & - & - & - \\
\hline I sode & $0 \circ 12$ & & - & - & - & - & - & - & - & - & - & - \\
\hline ma... & $?$ & & . & & & & & & & & & \\
\hline ST464 & 12 & ـ & & & & & & & & & & \\
\hline
\end{tabular}

a Symbol ' + ' indicates the cultivar (line) carry the tested genes; '-' indicates the cultivar (line) don't carry the tested genes. 
Table 6 (on next page)

Molecular detection of resistance genes Sr2, Sr24, Sr25, Sr26, Sr31, and Sr38 in the 75 wheat cultivars (lines) 


\begin{tabular}{|c|c|c|c|c|c|c|c|c|c|c|}
\hline \multirow[t]{2}{*}{ Cultivars (lines) } & $S r 2$ & $S r 2$ & $\mathrm{Sr} 24$ & $\operatorname{Sr} 24$ & $\operatorname{Sr} 25$ & $\operatorname{Sr} 26$ & Sr 31 & Sr31 & $\operatorname{Sr} 38$ & $\operatorname{Sr} 38$ \\
\hline & Xgwm533 & csSr2 & $\operatorname{Sr} 24 \# 12$ & $\operatorname{Sr} 24 \# 50$ & $G b$ & $\mathrm{Sr} 26 \# 43$ & SCSS30.2 $2_{576}$ & $\operatorname{Iag} 95$ & $U R I C-L N 2$ & VENTRIUP-LN2 \\
\hline Ningchun 39 & $--^{\mathrm{a}}$ & - & - & - & - & - & - & - & - & - \\
\hline Dingfeng 10 & - & - & - & - & - & - & - & - & - & - \\
\hline Linmai 32 & - & - & - & - & - & - & - & - & - & - \\
\hline Wuchun8 & + & - & - & - & - & - & - & - & - & - \\
\hline Wuchun 7 & - & - & - & - & - & - & - & - & - & - \\
\hline Dingxi 41 & - & - & - & - & - & - & + & + & - & - \\
\hline Longchun 31 & - & - & - & - & - & - & + & + & - & - \\
\hline Longchun 22 & - & - & - & - & - & - & - & - & - & - \\
\hline Ganchun 25 & - & - & - & - & - & - & + & + & - & - \\
\hline Longchun 25 & - & - & - & - & - & - & + & + & - & - \\
\hline Longchun 23 & - & - & - & - & - & - & + & + & - & - \\
\hline Longchun 26 & + & - & - & - & - & - & + & + & - & - \\
\hline Ganchun 24 & + & - & - & - & - & - & + & + & - & - \\
\hline Yinchun 9 & + & - & - & - & - & - & + & + & - & - \\
\hline Longchun 28 & - & - & - & - & - & - & - & - & - & - \\
\hline Wuchun 5 & - & - & - & - & - & - & - & - & - & - \\
\hline Ganchun 20 & - & - & - & - & - & - & - & - & - & - \\
\hline Ningchun 4 & - & - & - & - & - & - & - & - & - & - \\
\hline Linmai 35 & - & - & - & - & - & - & - & - & - & - \\
\hline Xihan 2 & - & - & - & - & - & - & - & - & - & - \\
\hline Dingxi 38 & - & - & - & - & - & - & - & - & + & + \\
\hline Ganchun 21 & + & - & - & - & - & - & - & - & - & - \\
\hline Dingxi 40 & - & - & - & - & - & - & - & - & - & - \\
\hline Wuchun 4 & - & - & - & - & - & - & - & - & - & - \\
\hline Wuchun 3 & - & - & - & - & - & - & - & - & - & - \\
\hline Jinchun 5 & - & - & - & - & - & - & + & + & + & + \\
\hline Gansu 26 & - & - & - & - & - & - & + & + & + & + \\
\hline Linmai 33 & - & - & - & - & - & - & - & - & + & + \\
\hline Longchun 33 & + & - & - & - & - & - & - & - & - & - \\
\hline Jiuchun 6 & + & - & - & - & - & - & - & - & + & + \\
\hline Longchun 27 & + & - & - & - & - & - & + & + & - & - \\
\hline Linmai 34 & - & - & - & - & - & - & - & - & - & - \\
\hline Dingfeng 12 & + & - & - & - & - & - & - & - & - & - \\
\hline Dingfeng 16 & - & - & - & - & - & - & - & - & - & - \\
\hline Zhangchun 21 & - & - & - & - & - & - & + & + & - & - \\
\hline Wuchun 6 & + & - & - & - & - & - & - & - & - & - \\
\hline Lantian 23 & - & - & - & - & - & - & - & - & - & - \\
\hline Lantian 19 & - & - & - & - & - & - & - & - & - & - \\
\hline Lantian 25 & - & - & - & - & - & - & - & - & - & - \\
\hline Lantian 13 & - & - & - & - & - & - & - & - & - & - \\
\hline
\end{tabular}


Xifeng 27

Lantian 26

Longjian 101

Hangxuan 1

Lantian 14

Lantian 31

Pingliang 42

Xifeng 20

Longyu 4

Changwu 131

Zhongliang 18

Zhongliang 22

Lantian 10

Tianxuan 39

Huandong 6

Longjian 196

Lantian 30

Longnan-2000-8-2-1

Longjian 301

Longyu 2

Longjian P430

Longjian 103

Lantian 29

Lan 092

Qingnong 1

Pingyuan 50

Longyuan 034

Lan 05-9-1-4

Gandong 017

Longjian 19

Lantian 24

863-13

01-426e-1

Tian 01-29

Tian 01-104

${ }^{a}$ Symbol '+' indicates the cultivar (line) carry the tested genes; '--' indicates the cultivar (line) don't carry the tested genes. 